\title{
MANAGING ECONOMIC DEVELOPMENT BY TOURISM CONTRIBUTION: EMPIRICAL EVIDENCE
}

\author{
PhD Biljana Petrevska, Assistant Professor, Faculty of Tourism and Business Logistics, Goce Delcev University \\ - Stip, Macedonia, e-mail: biljana.petrevska@ugd.edu.mk \\ PhD Margarita Matlievska, Assistant Professor, Faculty of Economics, Goce Delcev University - Stip, \\ Macedonia,e-mail: margarita.matlievska@ugd.edu.mk
}

\begin{abstract}
Tourism became one of the leading world industries thus provoking an interest among all countries, regardless the level of their economic development. Moreover, by increasing the number of incoming tourists, each country attempts to contribute to strengthening its economic growth. The paper addresses the economic impacts of tourism in Macedonia and makes an effort to assess its contribution to economic development. For that purpose, some commonly applied economic parameters are employed. The data set is observed in two sub-periods: $1991-2000$ as a period just after the independence of Macedonia and 2001-2010 as a period extensive enough to observe the first tourism outcomes. The research generally is covered by comparative analyses based on available sources of secondary data. The outcomes point to modest contribution of tourism towards economic development, and underscores the necessity for managing actions and measures for enhancing current status.

Economic Development: $\begin{array}{cc}\text { Key } & \text { words: } \\ \text { Economic Impacts; }\end{array}$
\end{abstract} Tourism; Management; Macedonia.

Introduction

Tourism industry is being defined as one of the most promising industries that mainly contribute to economic growth. So, tourism has been detected as a source for benefiting various sector and can trigger general economic progress by creating new dynamic. This research particularly intends to disentangle the contribution of tourism to economic development of Macedonia. In this line, the paper is composed of several sections. Section one presents a brief review of literature on tourism and economic development. Section two encompasses the methodological framework, while the main analyses, discussion and results are posted in Section three.

Generally, the main objective of this research is to point out the necessity for continuous analysis of tourism economic impacts as an important consideration to all tourism key-actors responsible for creating management strategies. Moreover, the main research findings may initiate urgent need for undertaking serious measures for enhancing tourism development in Macedonia.

\section{Literature review}

The issue referring the economic impacts of tourism and its effects on country's economic development is highly explored. Namely, numerous researchers have been involved and a wide variety of techniques have been applied in quantifying tourism economic effects. In this respect variety of methods, ranging from pure guesswork to complex mathematical models, are used to estimate tourism's economic impacts. Studies vary extensively in quality and accuracy, but mostly address economic impact analysis (Crompton, 1993; Lundberg et al, 1995; Huyberg, 2007; Babu et al, 2008; Ramos and Jimènez, 2008; Stabler et al, 2010). In this respect, the economic impact analysis traces the flows of spending associated with tourism activity in a region in order to 
identify changes in sales, tax revenues, income, and jobs due to tourism activity. The principal methods being applied are visitor spending surveys, analysis of secondary data, economic base models, input-output models and multipliers (Frechtling, 1994).

Due to fact that economic development represents just one process of a complex system known as human developement, means that economic developement enevitably leads to human developement and the quality of life (Osberg and Sharpe, 2003). So, the human developement or the increasement of human quality of life is the main goal of the economic development (Hayami and Godo, 2005; Kanbur, 2003).

In this respect, the achieved ecomomic and human developement may be measured and presented by various indicators (Cypher and Dietz, 2009; Grabowski et al, 2007; Soubbotina, 2004; Todaro and Smith, 2009):

(1) Value agregate indicators: dynamics and speed of growth of the total production; gross domestic product (GDP); degree of growth of GDP; degree of saving and index of investments or economic welfare etc.;

(2) Natural indicators: degree of infrastructural construction; degree of residential construction assistance; degree of biological nutritition of population etc.;

(3) Social indicators: nutritition, health, degree of education, social sequrity, working conditions, housing, employment etc.

\section{Methodology}

The paper is reach on different types of analysis mostly based on available sources of secondary data. Generally, comparable quantities are analysed with descriptive statistics on economic parameters for GDP and foreign direct investments (FDI). The data set applied in the research spreads over a twenty year horizon covering the period from 1991 to 2010. In order to gain more interesting and accurate outcomes, the main time series is divided in two sub-periods. The first subperiod covers the interval from 1991 until 2000 as a period just after the independence of Macedonia. The second interval is from 2001 until 2010 as a period when tourism is set in a broad macroeconomic framework and the first outcomes were present.

\section{Analysis, results and discussion}

During the research, several obstacles regarding the official statistical data representing tourism industry in Macedonia occurred. Namely, all applied statistical data refer only to hotels and restaurants in Macedonia, thus being a crucial limiting factor for more in-depth analyses. More precisely, it is very often the case that the term tourism in Macedonia is equal to the term hotel industry, which results into "neglecting various, even more significant effects compared to those produced within the hotel industry" (Sinclair and Stabler, 1997: 36). Additionally, the undertaken analyses refer only to direct tourism effects, meaning that the indirect ones are not addressed in this research. Up to date, some serious calculations or analyses regarding the multiplicative tourism effects in Macedonia have not been undertaken. However, considering the extremely low inter-sectional relationship and the trade deficit, it is expected that tourism multiplication in Macedonia is not very high. 


\subsection{Overall economic impact of tourism}

In case of analysing the economic importance of tourism in Macedonia, one may firstly address the issue of tourism contribution to overall economic activity. In this respect Table 1 presents the GDP created in hotel and restaurant sector in Macedonia during the sample period 19912010. As mentioned previously, the sample period is divided in two subperiods in order to point out more interesting concluding remarks. So, the first sub-interval addresses the first 10 years just after the independence of Macedonia. It is noticeable that the GDP created in tourism within this period decreased in six out of ten years, which might be explained as a post-independence period. The 1996 performed the best results and together with 2003 are the highest peaks, approximately $0.2 \%$ above the average tourism contribution to the economy in the sample period. As presented in Table 1, during the sub-period 1991-2000, the average annual growth is $0.6 \%$ and $1.5 \%$ as tourism contribution to the GDP.

Table 1. GDP of tourism in Macedonia, 1991-2010

\begin{tabular}{|c|c|c|r|r|c|}
\hline Year & $\begin{array}{c}\text { Annual growth } \\
(\%)\end{array}$ & $\begin{array}{c}\text { \% of } \\
\text { GDP }\end{array}$ & Year & $\begin{array}{c}\text { Annual } \\
\text { growth (\%) }\end{array}$ & $\begin{array}{c}\% \text { of } \\
\text { GDP }\end{array}$ \\
\hline 1991 & 7.4 & 1.7 & 2001 & -4.5 & 1.5 \\
\hline 1992 & -8.9 & 1.6 & 2002 & 16.6 & 1.7 \\
\hline 1993 & -2.7 & 1.5 & 2003 & 9.6 & 1.8 \\
\hline 1994 & -8.4 & 1.4 & 2004 & -1.7 & 1.7 \\
\hline 1995 & -12.6 & 1.3 & 2005 & 4.8 & 1.7 \\
\hline 1996 & 4.1 & 1.8 & 2006 & 8.5 & 1.7 \\
\hline 1997 & -3.6 & 1.4 & 2007 & 5.9 & 1.7 \\
\hline 1998 & 7.3 & 1.4 & 2008 & -8.6 & 1.6 \\
\hline 1999 & 24.7 & 1.7 & 2009 & -9.2 & 1.4 \\
\hline 2000 & -1.3 & 1.5 & 2010 & 2.3 & 1.6 \\
\hline $1991-2000$ & 0.6 & 1.5 & $2001-2010$ & StD: $8.4 \%$ & \\
\hline & StD: $10.9 \%$ & & &
\end{tabular}

The second analyzed sub-period that covers the interval 2001-2010, generally performed growth, which was yet, very volatile. For instance, in 2001 and 2004 the GDP created in tourism decreased compared to the previous year. However, it has to be pointed out that the negative growth rate in these years is partially due to the war conflicts in Macedonia and the region. For example, 
the extreme fall of tourism activity in 2000, can be interpreted as a consequence of the Kosovo war, bomb attacks on Serbia and refugee crisis in 1999. Such conclusion throws a shade on unexpected extremely high growth of tourism sector in 2003 (when actually all these negative shocks still had an influence), which can be elaborated as an outcome of abstinence of domestic population for travelling abroad i.e. an increase in domestic tourism demand. Further on, a fall of the GDP is noted in 2004, which can be provoked by increased interest for travel abroad, caused by the recovered economic activity and the rising consumer lending. In the rest of analysed sub-period, tourism sector shows a slight growth with uneven intensity. As it can be seen in Table 1, this second analyzed sub-interval contributed much more to the economic development of Macedonia. Namely, the average annual growth is $2.3 \%$ which is approximately 4 times higher than the average of the first analyzed sub-period.

Generally speaking, it can be noted that the economic importance of tourism in 1996 and 2003 reached its peak of $1.8 \%$ in total GDP. In the same line, during the sample period 1991-2010 the tourism, in average, generated $1.6 \%$ of the GDP. Compared to the world average of $3.2 \%$ in 2009 (WTTC, 2009a: 4) lead us to conclusion of very modest tourism contribution. Yet, the impression is completely opposite when making comparison to the average for Central and Eastern Europe (CEE) being 1.6\%. (WTTC, 2009b: 5).

It is calculated that in the less developed countries, one percent of the GDP allocated to debt repayment reduces investment by 0.3 percent of the GDP, which inhibits investment (Cohen, 1993). This implies that additional receipts from international tourism as a proportion of national income increases investment by 0.3 percentage, as well as saving foreign currency expenses.

The lack of Tourism Satellite Accounts (TSA) is additional restrictive factor for "perceiving the final impact on entire economy" (WTTC/WEFA, 2007: 35). The absence of TSA concept prevented us to implement it as "a measure of added value and to identify the tourism influence on the entire national economy" (Spurr, 2006: 286). Moreover, the TSA can guide policy decision makers in their strategic choices, helping them to understand size and importance of tourism sector as a whole. In this respect, the indicators for the TSA are more and more used as targets in national tourism policies and long-term strategies (OECD, 2010).

\subsection{Foreign direct investments and foreign trade}

In this part we address the issue of FDI and the foreign trade in Macedonia during the past 20 years. Regarding the FDI, some interesting concluding remarks were pointed out. Namely, from the figures presented in Table 2 is obvious that in the very first years of independency, the annual growth in Macedonia has a negative sign. However, the maximum is encountered in 1994, when the FDI had the highest rate within the sample period of 2251.2\%. Moreover, from less than US\$ 1 million in 1993, the FDI increased to around US\$ 20 million. In the rest of the years within the first analyzed sub-period covering 1991-2000, the FDI had unregularly ups and downs. The result is an average of 38 million US\$, which may be interpreted as a realistic outcome and an average annual growth rate of $317 \%$ due to the unnaturally high score in 1994. 
Table 2. Foreign direct investments in Macedonia, 1991-2010 (000 US\$)

\begin{tabular}{|c|c|c|c|c|c|}
\hline Year & FDI & Growth (\%) & Year & FDI & Growth (\%) \\
\hline 1991 & 11881 & - & 2001 & 449104 & 194.9 \\
\hline 1992 & 2207 & -81.4 & 2002 & 77812 & -82.7 \\
\hline 1993 & 812 & -63.2 & 2003 & 80643 & 3.6 \\
\hline 1994 & 19092 & 2251.2 & 2004 & 139460 & 72.9 \\
\hline 1995 & 8353 & -56.3 & 2005 & 116168 & -16.7 \\
\hline 1996 & 7187 & -14.0 & 2006 & 350665 & 201.9 \\
\hline 1997 & 30902 & 323.0 & 2007 & 330802 & -5.7 \\
\hline 1998 & 112308 & 263.4 & 2008 & 356400 & 7.7 \\
\hline 1999 & 38079 & -66.1 & 2009 & N/A & N/A \\
\hline 2000 & 152270 & 299.9 & 2010 & N/A & N/A \\
\hline $1991-2000$ & 38309 & 317.4 & $2001-2010$ & 237632 & 47.0 \\
\hline
\end{tabular}

Table 3. Volume of import and export of goods and services (annual rates in \%)

\begin{tabular}{|c|c|c|c|c|c|}
\hline Year & Import & Export & Year & Import & Export \\
\hline 1991 & - & - & 2001 & -15.1 & -15.6 \\
\hline 1992 & -3.0 & - & 2002 & 9.7 & -5.1 \\
\hline 1993 & 48.4 & -5.1 & 2003 & -15.1 & -5.9 \\
\hline 1994 & 25.7 & 1.4 & 2004 & 16.7 & 13.1 \\
\hline 1995 & -1.0 & -0.6 & 2005 & 6.2 & 11.0 \\
\hline 1996 & -7.3 & -10.7 & 2006 & 10.9 & 8.3 \\
\hline 1997 & -10.5 & -11.0 & 2007 & 16.3 & 12.0 \\
\hline 1998 & -3.0 & -3.6 & 2008 & -0.1 & -7.0 \\
\hline 1999 & -0.2 & 6.2 & 2009 & -15.3 & -16.0 \\
\hline 2000 & 27.3 & 20.4 & 2010 & 11.4 & 24.1 \\
\hline $1991-2000$ & 8.5 & -0.4 & $2001-2010$ & 2.6 & 1.9 \\
\hline
\end{tabular}

Source: International Monetary Fund, World Economic Outlook Database, 2011, p. 12.

As up to the second sub-period covering 20012010 , it is noticeable that due to the war conflict in Macedonia in 2001, the FDI hardly accomplished US\$ 80 million in 2002 and 2003. Nevertheless, the general picture is completely different when addressing the 
years that follow when an upward trend is present. Specifically, as of 2006 the FDI in Macedonia gain in some importance for economic development, thus resulting with an average of 238 million US\$ and an average annual growth of $47 \%$.

Table 3 presents data regarding the average annual percentage rate of foreign trade of goods and services during the sample period. In this respect, the first sub-period generally is characterized with high average annual import rate of $8.5 \%$ and an average annual export rate of $-0.4 \%$. During this first sub-period it has to be mentioned that in 1993, the peak of $48.4 \%$ was reached as the peak point ever. On the other hand, the annual export rates within this sub-interval show the lowest point in 1997 of $-11.0 \%$, while the top limit was $20.4 \%$ in 2000.

The second sub-period covers 20012010, whereas 2001 and 2009 are years with significantly negative outcomes regarding import and export of good and services. The reasons are evident due to the fact that in 2001 a war conflict appeared in Macedonia, and in 2009 the negative effects out of the world financial crisis were present. In this respect the annual import rates were $-15.1 \%$ and $-15.3 \%$ respectfully. Regarding the export of good and services during this period, it is also noticeable that the above mentioned years scored the lowest export rates i.e. $-15.6 \%$ in 2001 and $16 \%$ in 2009. Despite the negative effects in post-recession period, the first positive impulse is noted in 2010 of $24.1 \%$ as the highest annual export rate within the sample period in general. Moreover, the average annual import rate for this sub-period was $2.6 \%$ and the average annual export rate of goods and services was $1.9 \%$. It can be concluded that Macedonian economy recovered from the negative outcomes noted within the decade of independence.

\section{Conclusion}

This study emphasized that tourism contribution within the economic development in Macedonia is important principally when compared to the average figures of tourism trends in the CEE. Namely, the economic effects are with considerable impact if measured by the participation in creating the GDP (1.6\%). However, the additional outcomes of the analysis referring the FDI point to necessity of undertaking serious measures for enhancing economic development. Besides, the analyses of both sub-intervals within the sample period indicate that tourism in Macedonia fully recovered from the independence period when only modest results were performed.

The findings point to the note that Macedonia is short on global concept for tourism development. If one wants to apply positive tourism impacts on the economy, than as an important consideration for economic development must be introduced the process of state, regional and community planning and management. More precisely, Macedonia must be reach on developmental management process particularly for supplementary sectors necessary for tourism follow-up development. Herein, tourism in Macedonia should be observed in broad, macroeconomic frames as specific market segment whose dimensions and economic content comprehensively may be interpreted within the quantity and structure of tourism expenditure. That is possible only by creating analytical frame for identifying all tourism impacts.

Due to variety of obstacles when ensuring all-inclusive and reliable statistical data addressing tourism industry, the objective assessment of tourism influence on the economic development in Macedonia is very difficult, almost infeasible. Accordingly, the paper underscores the need for continuous analysis of tourism economic impacts as an important consideration to all tourism keyactors responsible for creating economic development management strategies in Macedonia. In this respect, the main conclusions of the analysis should initiate urgent need for undertaking serious measures and activities for enhancing tourism and, simultaneously economic development in Macedonia. 


\section{References}

1. Babu, S. S., Mishra, S. \& Parida, B. B. (2008). Tourism development revisited: concepts, issues and paradigms, Saga.

2. Cohen, D. (1993). Low investment and large LDC debt in the 1980's, American Economic Review, 83(2).

3. Crompton, J. L. (1993). Economic impact analysis: Myths and misapplication, Trends, 30(4), 9-14.

4. Cypher, M., J. \& Dietz, L., J. (2009). The process of economic development, Routledge.

5. Frechtling, D. C. (1994). Assessing the economic impacts of travel and tourism Introduction to travel economic impact estimation, in: Ritchie, J. R. B., Goeldner, C. R. (Eds). Travel, Tourism and Hospitality Research, John Wiley and Sons.

6. Grabowski, R., Self, S. \& Shields, P. M. (2007). Economic Development; A Regional, Institutional and Historical Approach, Sharpe Inc.

7. Hayami, Y. and Godo, Y. (2005). Development Economics: from the Poverty to the Wealth of Nations, Oxford University Press.

8. Huyberg, T. (2007). Tourism and developing countries, Edward Elgar Publishing.

9. International Monetary Fund (2011). World Economic Outlook Database.

10. Kanbur, R. (2003). Conceptual challenges in poverty and inequality: Onedevelopment economist's perspective, Cornell University.
11. Lundberg, D., Donald, E., Krishnamoorthy, M., Stavenga, H. (1995). Tourism Economics, John-Wiley.

12. OECD (2010). OECD Tourism trends and policies 2010.

13. Osberg, L. \& Sharpe, A. (2003). Human Well Being and Economic Well Being; What Values Are Implicit in Current Indices?, Canada.

14. Ramos, A. D. \& Jimènez, P. S. (2008). Tourism development: economics, management and strategy, Nova Science Pub.

15. Sinclair, T. M. \& Stabler, M. (1997). The Economics of Tourism, Routledge.

16. Soubbotina, T. (2004). Beyond Economic Growth: An Introduction to Sustainable Development, The World Bank.

17. Spurr, R. (2006). Tourism Satellite Accounts, in: Dwyer, L. et al. (Ed.). International Handbook on the Economics of Tourism, Edward Elgar Publishing.

18. Stabler, M., Papatheodorou, A. \& Sinclair, T. (2010). The Economics of Tourism, Taylor \& Francis.

19. Todaro, P. M. \& Smith, C. S. (2009). Economic Development, Pearson Education Lmtd.

20. WTTC. (2009a). Travel \& Tourism Economic Impact, Executive Summary 2009.

21. WTTC. (2009b). Travel \& Tourism Economic Impact - Central and Eastern Europe 2009.

22. WTTC/WEFA. (2007). Travel \& Tourism Satellite Accounting Development Program - An Integrated Econometric System for Measuring and Forecasting Travel \& Tourism's Contribution to National Economies, London. 